\title{
APPROACHES, METHODS AND TOOLS OF RIGHTS OF ACCESS TO SUNLIGHT AROUND THE WORLD
}

Jozef Hraška ${ }^{*}$

\section{Abstract}

Sunlight has always played an important role in the design of human settlements. Well-designed urban structures, especially in moderate or cold climates, should be assured of direct sunlight in indoor living spaces and also in public spaces. Direct sunlight in a built environment is an important factor for health and well-being, the effective functioning of solar systems, and sustainable construction. However, many problems involved in the exercise of rights of access to sunlight can arise when sunlight is obscured by a tall cityscape. Many states, regions, and cities regulate solar access, but solar rights and landowner rights are in a permanent conflict. The high urban density of many cities with tall skyscrapers accentuates the problem of the availability of sunlight. This paper presents a review of existing regulations and metrics for ensuring the availability of direct sunlight in buildings and of assessment methods that have been adopted in multiple countries and cities. Approaches, methods, and tools of rights of access to sunlight are critically analyzed. The paper also details experiences from former socialist countries where strict long-term strict on direct access to sunlight in flats were applied.

\section{Address}

1 Department of Building Construction, STU Bratislava, Faculty of Civil Engineering, Radlinského 11, 81368 Bratislava, Slovakia,

* Corresponding author: jozef.hraska@stuba.sk

\section{Key words}

- Solar rights,

- Access to sunlight,

- Urban design,

- Solar envelope,

- Owershadowing.

\section{INTRODUCTION}

Throughout history, sun and daylight have shaped human settlements and individual buildings. Modern technologies, efficient artificial light sources, and socio-economic processes have put pressure on traditional urban structures and building dimensions. Rapid population growth and moving people into cities is causing an increase in the density of the existing urban fabric associated with the construction of tall buildings. However, adequate solar access in a built environment is generally considered to be important to people's health, well-being, and daily life (Neeman et al., 1976; Boubekri, 2008; Holick, 2008; Hodbay, 1997). The right to access and harvest sunlight is an important human right. The availability of direct sunlight in apartments not only has health and psychological effects but also has urban, architectural, social, hygienic, energy and econom- ic consequences. Sustainable and energy-efficient construction has increased interest in the use of solar radiation. Selected criteria for solar rights greatly influence the density of development, the design of public spaces and transport, and other urban planning contexts. So, protecting solar and daylight rights in urban areas is a very complex task. In particular, dense high-rise urban areas dramatically reduce the amount of sunlight and diffuse skylight in the surrounding buildings and public spaces. High-rise buildings struggle for access to the sun and daylight with each other.

It is extremely important that solar and daylight rights are considered at an early stage of urban planning. For low and medium-density zones there are a number of procedures and tools for their design that respect solar rights and access to sunlight (Littlefair, 2011; Hraška, 2004; Darula et al., 2015; Hachem et al., 2013). In urban areas with high-rise buildings there are specific conditions for solar rights, but 
there are no reliable design tools available. We do not mean various graphic tools and computer programs that can be used, but we mean rules for the layout of tall buildings within urban zones. In many cities around the world, the rules for the layout of buildings are so relaxed that buildings significantly higher than 100 meters are only a short distance apart, Fig. 1. Ensuring sufficient sunlight and natural light in buildings is illusory under such conditions. In recent years, the trends of "green" and "sustainable" buildings have brought increased interest in research on daylight and sunlight in urban planning and architecture (Chynoweth, 2009; Hraška, 2011; Cheng et al., 2006; Seong, et al., 2006; Lobaccaro and Frontini, 2014; Lopore, 2017).

Research on the energy and environmental aspects of solar radiation has become more complex due to the widespread use of sophisticated simulation and experimental methods (Shaviv and Yezioro, 1997; Capeluto abd Shaviv, 2001; Dogan et al., 2012; Kima and Yi, 2019; Yi and Kima, 2015; Compagon, 2004; Ekici et al., 2019; Ratti and Morello, 2005; Seong et al., 2011; López et al., 2016; Teller, 2001; Mardaljevic and Rylatt, 2003; De Luca and Dogan, 2019; Perey, 2011; Lia et al., 2019; Yhang et al., 2012; Mohajeria et al., 2019). Interest in the impact of solar radiation on human health has been significantly renewed and emphasized. Research on the non-visual effects of daylight has especially brought new knowledge about the physiological and psychological well-being and performance of humans in indoor environments (Arues et al, 2015; Pauley, 2004; Rea et al., 2012). The results of these researches have no practical significance without actual daylight and direct access to sunlight in many types of buildings. In general, land-use regulations, especially in the central parts of cities, often clash with the requirements for daylight and sunlight.

The purpose of this paper is to provide an overview of regulations and standards to ensure the availability of sunlight in residential buildings in different countries and cities, as well as the calculation methods in this field. In this article we are not only concerned with the technical issues, but also with their broad context.

\section{CONCEPTS OF SOLAR RIGHTS}

The availability of solar energy to a property increases its value by enriching the quality of the built environment and renewable energy potential. Concepts for ensuring the availability of solar radiation vary in terms of the purpose for which they are adopted and in terms of the criteria and the way they are assessed and verified. Historically and empirically, solar and daylight laws were based on rules of obstruction angles. A $45^{\circ}$ obstruction was considered as a suitable standard in the medium latitudes of Europe. Especially in the central parts of some larger European cities in the southern latitudes, obstruc-

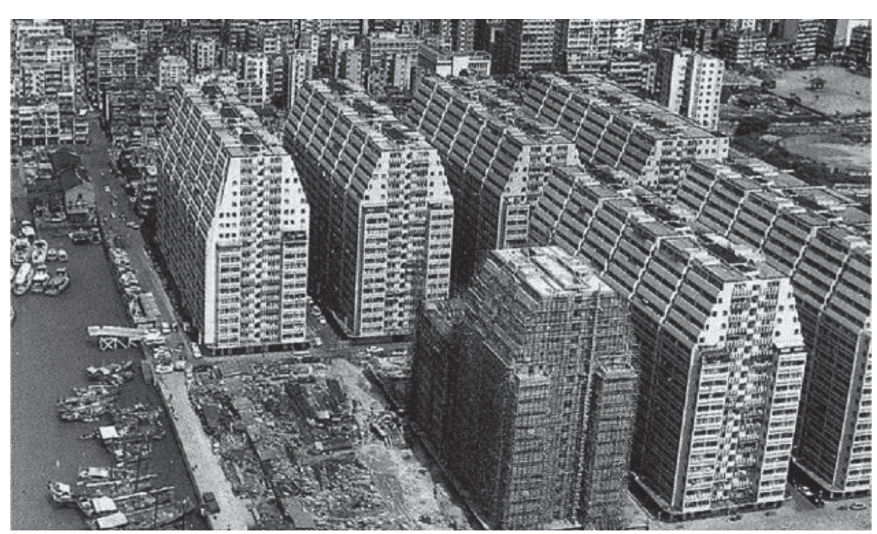

Fig. 1 Residential buildings in Hong Kong (Ng, 2003) tions of $60^{\circ}$ degrees were allowed. This practice guarantees a certain minimum access to natural light, but not enough availability of direct sunlight on the windows. A $45^{\circ}$ obstruction did not allow access to the sun on the lower floors of buildings in traditional street canyons during the cold season of the year.

In the second half of the $20^{\text {th }}$ century, concepts of access to direct sunlight (or solar rights) were adopted in various countries to guarantee its availability, especially in apartments. In the former socialist countries (the Soviet Union, Czechoslovakia, Poland, etc.) the availability of direct sunlight in each apartment and in apartment-like accommodations was considered as a hygienic standard guaranteed by law. It was understood as an actual fulfillment of constitutional rights guaranteeing healthy living conditions for all the inhabitants. The minimum number of hours of access to sunlight during critical periods of the day and the year was required not only for new apartments, but also for all the existing dwellings surrounding them, see Tab. 1. Solar and daylight rights were superior to municipal regulations, historical heritage conservation, etc. Solar rights could not be sold in these countries. One consequence of such a concept of solar rights is that new buildings had to adjust their size and shape according to the solar rights of neighboring apartments. Thus, some version of the well-known solar envelope method (Knowles, 2003) was used in the former socialist countries since the 1950s. These strictly enforced solar rights in many cases led to the deformation of new buildings, Fig. 2. Particular problems arose when the existing dwelling did not meet the standardized access to sunlight before a new building was proposed in their neighborhood. In various former socialist countries, this practice is still in place today. It was also a problem that dwellings in new buildings could obtain the required time of access to direct sunlight throughout the "critical" day if the sun's altitude was only $5^{\circ}$ above the horizon, for example, in what is now Slovakia. Consequently, new buildings were often disproportionately restricted in their broader surroundings.

In several Asian countries where very tall buildings were being built, public petitions were initiated against their unregulated construction. After extensive discussions, various Asian states adopted solar rights in their civil law systems, respectively in zoning regulations or building codes. These solar rights were based on health and well-being. The infringement of solar rights is dealt within the framework of laws on neighbors or easement contracts. In Japan developers must compensate residents for buildings casting shadows more than is allowed by law, for example.

In the US and some other countries, the availability of direct sunlight in apartments is not guaranteed in the civil law (Bronin, 2009;

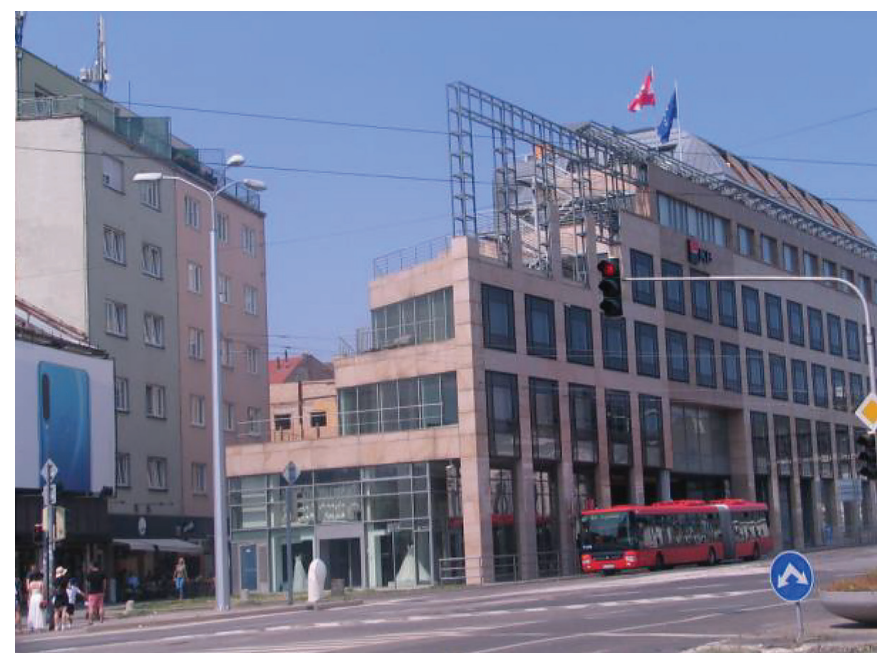

Fig. 2 Solar envelope of a new building providing solar rights for flats in the central part of Bratislava, Slovakia 
Rosenthal, 2013). Specifically in the US, the defense of dense and tall construction quotes from Roman law "for whoever owns the soil, it is theirs up to Heaven and down to Hell". The well-known decision of Emperor Justinian that no neighbor can block the light "previously enjoyed for heat, light or sundial operation" is less reported.

In the US, the term "solar rights" usually refers to the right of a property owner to install a solar system. Solar rights arose in response to the energy crisis in the 1970 s. A solar thermal, lighting or photovoltaic system obviously needs direct access to sunlight. Solar rights acts allow property owners some access to direct sunlight and the installation of solar collectors to protect against excessive shading. The legal protection of solar access usually requires compensation. In the US there was a problem with the legal interpretation of the right to the availability of direct sunlight. Oil and gas laws were considered as one of the sources of inspiration in this matter. According to oil and gas law, "...the opportunity to extract oil or gas is distributed in proportion to property ownership of mineral rights under areas of land surface" (Reitze, 1976). Thus, larger owners have the right to use more solar radiation.

We can also look at the issue of solar rights through the optics of "stolen direct sunlight and solar energy", i.e., someone uses natural resources at the expense of another. The solar envelope method is considered to be one of the protective measures to correct this problem (Knowles, 2003). It establishes the maximum volume and shape of a newly designed building that does not violate the solar rights of neighboring dwellings. Classic solar envelopes generated

Tab. 1 Direct access to sunlight according to legal regulations

\begin{tabular}{l|l}
\hline State & \multicolumn{1}{c}{ Requirements } \\
\hline Russia & $\begin{array}{l}\text { A minimum time of access to direct sunlight in dwellings in zones above the } 58^{\circ} \mathrm{N} \text { latitude is required for } 2.5 \text { hours } \\
\text { in the period from April } 22 \text { to August } 22, \text { in the zones between } 58^{\circ} \mathrm{N} \text { and } 48^{\circ} \mathrm{N}, 2.0 \text { hours are required in the } \\
\text { period from April } 22 \text { to August 22, and in zones of latitudes of less than } 48^{\circ} \mathrm{N} 1.5 \text { hours is required in the period } \\
\text { from February 22 to October 22. If the access to sunlight is intermittent, access is required for } 0.5 \text { hours longer, but } \\
\text { an uninterrupted period of access to sunlight of at least } 1 \text { hour must be met. For buildings located in historic city } \\
\text { centers, access to sunlight can be reduced by } 0.5 \text { hours (San PiN 2.2.1/2.1.1.1076-01). }\end{array}$ \\
\hline
\end{tabular}

\begin{tabular}{l|l} 
Czech Republic & At least 1.5 hours from March 1 or the balance of the sunlight's duration in the period from February 10 to March
\end{tabular} 21 of at least 1.5 hours is required for all new dwellings and, with minor exceptions, for all existing dwellings (Regulation No. 268/2009; ČSN 73 4301:2004).

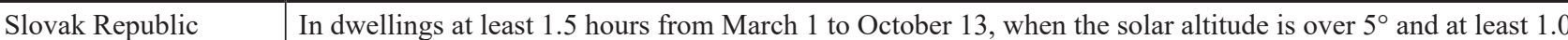
hours in the historical central parts of cities. The same legal requirements for the availability of direct sunlight are applied to newly-built dwellings as well as to all existing dwellings. Kindergartens are required to have at least 1.5 hours of direct access to sunlight between 10 a.m. and 3 p.m.; the same requirement is applied for children's outdoor play areas (Regulation No. 532/2002; STN 73 4301:2005).

\begin{tabular}{l|l}
\hline Poland & $\begin{array}{l}\text { A minimum of } 3 \text { hours between } 7 \text { a.m. and } 5 \text { p.m. from March } 21 \text { in residential buildings and at least } 1.5 \text { hours } \\
\text { if the dwelling has only one living room. In schools and child care buildings, the availability of } 3 \text { hours of direct } \\
\text { sunlight is necessary between } 8 \text { a.m. and } 4 \text { p.m., while for children's outdoor play areas is access to sunlight re- } \\
\text { quired for } 4 \text { hours or at least } 2 \text { hours in the town centres (Regulation No. 620/2002). }\end{array}$
\end{tabular}

People's Republic of China

Access to sunlight depends on the size of the city and on the climate zone in which the dwelling is located. For example, the standard for residential buildings requires at least 2 hours in metropolises and 3 hours in small to medium cities on the "Great Cold Day" (January 20) between 8 a.m. and 4 p.m in climate regions I, II, III, and VII (People's Republic of China, Ministry of Construction, 1993).

\begin{tabular}{l|l} 
Japan & Japanese cities are divided into several types of zones and several categories, in which heights and distances of
\end{tabular} buildings are prescribed; laws also assess the shadows cast by a proposed building on neighboring plots. Shadows are evaluated at the winter solstice from 8 a.m. to 4 p.m. at different heights above the terrain, depending on the type of zone (for example in a low-rise residential area, the height above the terrain is $1.5 \mathrm{~m}$, but in a commercial or industrial zone no such evaluation is done). The distance of a shadow cast from the border of the plots is usually from 5 to $10 \mathrm{~m}$. Shaded parts of the neighboring parcels can be shaded for 3 to 5 hours (Urban Land Use Planning System in Japan, 2007).

Republic of Korea $\quad$ More than 2 hours in every housing unit during the winter solstice from 9 a.m. to 15 p.m. is required, in the case of accumulative access to sunlight; access to sunlight must be more than 4 hours. The distance between each block should be kept to more than 0.8 times a building's height to the south from a neighboring apartment building (Korean Legislation Research Institute, 2009).

\begin{tabular}{l|l} 
Japan & Japanese cities are divided into several types of zones and several categories, in which heights and distances of
\end{tabular} buildings are prescribed; laws also assess the shadows cast by a proposed building on neighboring plots. Shadows are evaluated at the winter solstice from 8 a.m. to 4 p.m. at different heights above the terrain, depending on the type of zone (for example in a low-rise residential area, the height above the terrain is $1.5 \mathrm{~m}$, but in a commercial or industrial zone no such evaluation is done). The distance of a shadow cast from the border of the plots is usually from 5 to $10 \mathrm{~m}$. Shaded parts of the neighboring parcels can be shaded for 3 to 5 hours (Urban Land Use Planning System in Japan, 2007).

Republic of Korea More than 2 hours in every housing unit during the winter solstice from 9 a.m. to 15 p.m. is required, in the case of accumulative access to sunlight; access to sunlight must be more than 4 hours. The distance between each block should be kept to more than 0.8 times a building's height to the south from a neighboring apartment building (Korean Legislation Research Institute, 2009). 
Tab. 2 Direct access to sunlight in state standards

\begin{tabular}{l|l}
\hline State & \multicolumn{1}{c}{ Requirements } \\
\hline Germany & $\begin{array}{l}\text { At least one room of a dwelling needs to receive } 4 \text { hours on March } 21^{\text {st }} \text {, an additional criterion is } 1 \text { hour of access } \\
\text { to sunlight on January } 17^{\text {th }} \text { (DIN 5034-1:2011-07). }\end{array}$ \\
\hline U.K. & $\begin{array}{l}\text { A room should receive at least 25\% of the annual probable sunlight hours. 5\% of the required direct sunlight should } \\
\text { be accessed from September 21 to March 21 (BS 8206-2:2008). }\end{array}$ \\
\hline Estonia & 3 hours of sunlight from April 22 to August 22 (RT I 2002). \\
\hline Slovenia & At least 2 hours on December 21 $1^{\text {st }}, 4$ hours on March 21 $1^{\text {st }}$, and 6 hours on June 21 $1^{\text {st }}(\mathrm{TSG}-1-004: 2010)$. \\
\hline European Union & $\begin{array}{l}\text { Minimum exposure to sunlight should be provided in patient rooms in hospitals, play rooms in nurseries, and at } \\
\text { least one habitable space in dwellings. The selected date for assessments of exposure to sunlight should be between } \\
\text { February 1 and March 21. The standard sets a minimum exposure to sunlight of 1.5 hours from the minimum alti- } \\
\text { tude of the sun, which varies from one EU country to another. The standard recommends achieving longer times of } \\
\text { sunlight exposure, i.e., 3 or 4 hours (EN 17037:2018). }\end{array}$ \\
\hline
\end{tabular}

Table 3 Direct access to sunlight according to the ordinance of the municipality

\begin{tabular}{|c|c|}
\hline City & Requirements \\
\hline Sydney (Australia) & $\begin{array}{l}\text { Living rooms and private open spaces of at least } 70 \% \text { of apartments in a building should receive a minimum of } 2 \\
\text { hours of direct sunlight between } 9 \text { a.m. and } 3 \text { p.m. on December } 21^{\text {st }} \text { in specified areas with a dense development; } \\
\text { a minimum of } 3 \text { hours of direct sunlight is required in other areas. A maximum of } 15 \% \text { of apartments in a building } \\
\text { can receive no direct sunlight on the above specified date and time (SEPP } 65 \text { ). }\end{array}$ \\
\hline $\begin{array}{l}\text { Auckland } \\
\text { (New Zealand) }\end{array}$ & $\begin{array}{l}\text { At least } 70 \% \text { of living rooms and private open spaces in a development should receive a minimum of } 3 \text { hours of } \\
\text { direct sunlight between } 9 \text { a.m. and } 3 \text { p.m. in mid-winter. } \\
\text { Single aspect apartments oriented towards cardinal points with no direct sunlight in mid-winter should account for } \\
\text { a maximum of } 10 \% \text { of the total units proposed. Developments that do not meet this minimum should be able to } \\
\text { demonstrate how the site constraints and orientation prohibit these standards from being achieved, and how issues } \\
\text { of energy efficiency will be addressed (Auckland design manual, 2018). }\end{array}$ \\
\hline $\begin{array}{l}\text { Boulder, Colorado } \\
\text { (USA) }\end{array}$ & $\begin{array}{l}\text { New buildings cannot cast shadows on surrounding facades where heights are different, depending on the Solar } \\
\text { Access Area (Area I } 3.66 \mathrm{~m} \text {, Area II 7.62, Area III no shadow line) between } 10 \text { a.m. and } 2 \text { p.m. on December } 21 \\
\text { (Solar Access Guide, 1981). }\end{array}$ \\
\hline $\begin{array}{l}\text { Ashland, Oregon } \\
\text { (USA) }\end{array}$ & $\begin{array}{l}\text { A new building cannot cast a shadow taller than } 1.83 \mathrm{~m} \text { on the most northern point of its own property line on De- } \\
\text { cember } 21 \text { at } 12 \text { a.m. (Solar Access, 2011). }\end{array}$ \\
\hline Vienna (Austria) & $\begin{array}{l}\text { Residents in Vienna do not have the right to complain that their flat or other part of a property does not have enough } \\
\text { access to sunlight, as defined by the municipal regulations. The urban planning of Vienna clearly defines the condi- } \\
\text { tions of development, which are controlled by the competent authorities (Stadt Wien, 2009). }\end{array}$ \\
\hline Zurich (Switzerland) & $\begin{array}{l}\text { Zurich restricts the length of time of sunlight for a high-rise addition to residential areas. A tall building can cast } \\
\text { shadows on a horizontal surface of a plot, but is limited to less than } 3 \text { hours on November } 3 \text { or February } 8 \text { between } \\
8 \text { a.m. and } 4 \text { p.m. (Kanton Zürich, Baudirektion, Allgemeine Bauverordnung). }\end{array}$ \\
\hline
\end{tabular}

pyramid-shaped buildings that resembled a parody of urbanism. The wide and deep lower floors of such buildings did not use daylight and required mechanical ventilation, which cannot be considered as an environmentally and energy-efficient approach to building design.

There are a large number of variations and modifications to the solar envelope method (Hraška, 2004; Capeluto and Shaviv, 2001; Morello, 2009; Capeluto, 2001; Vartholomaios, 2015; Cotton, 1996). Most publications on this topic address the technical side of the problem. More recent scientific work in this field deals with solar radiation simulations that analyze regular urban structures, an array of buildings, urban canyons, and regular urban blocks that rarely occur in real life (Cheng et al., 2006; Panão et al., 2008; Stasinopoulos, 2018; etc.). Year-round simulations of the irradiance of building surfaces in complex urban structures in which winter and summer are mixed are not suitable for the initial design stages of an urban structure or a building. They are not particularly suitable where there is a civil law guaranteeing access to sunlight in all dwellings or other interior and exterior spaces. However, the technical details of the solar envelope method are not of primary importance, but the philosophy behind the issue and the accepted criteria are essential.
Solar rights are closely linked to concepts such as "social equity", "public health", a "post-carbon society", "green buildings", a "solar city", morals, general welfare, etc. The application of such concepts has a number of legal and political implications. To what extent can these concepts be filled with real content at a time when tall buildings are densely built in cities around the world? Can access to sunlight be based on rights that contradict urban planning? Conversely, can a "healthy" and "sustainable" city be planned without reasonably applied solar rights? The philosophical bases of the rights to sunlight are of a humane and anthropocentric nature.

The minimum criteria for the availability of direct sunlight should be unambiguous, taking into account the expectations of people and the actual possibilities for their fulfillment. The criteria should also be clearly and easily verifiable. It is apparent from Tabs. 1 to 3 that the criteria for direct access to sunlight that are applied in practice have a simple space-time character. Clear criteria and methods for their verification are needed for agreements between property owners, zoning ordinances, and court litigation. It is true that possible and probable sunlight hours vary from region to region. The availability of sunlight in the morning and the afternoon is different and also varies from 


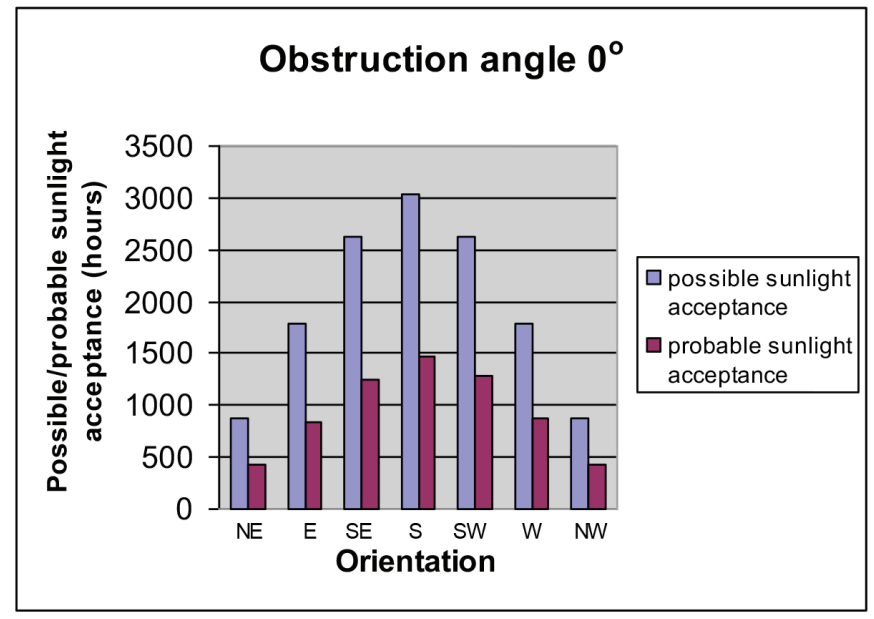

Fig. 3 Annual possible/probable direct access to sunlight on windows facing towards different cardinal points in Bratislava, Slovakia (Hraška, 2004)

month to month, while the availability of sunlight at a given location affects the vegetation, self-shading, surface reflectance, and other specifics. According to (Hraška, 2004), there are relatively small differences in the evaluation results of possible or probable direct access to sunlight on a year-round basis in a specific location, see Fig. 3. Taking into account these and other specifics in the early stages of designing is counterproductive and relativizes the substance of the issue. Determining the date and time of direct access to sunlight requires a cautious approach in order to achieve an acceptable balance between the benefits of solar access and urban development needs. There is no fundamental difference in whether we assess solar rights by the time of direct access to sunlight or by the time of the shading of the evaluated site. However, when assessing the availability of direct sunlight in specific apartments, unexpected complications may arise. As mentioned above, situations where direct access to sunlight in existing apartments does not meet current criteria are problematic.

\section{TOOLS OF RIGHT OF ACCESS TO SUNLIGHT}

For effective policy implementation, the simplest and most transparent methods with graphic interpretations are appropriate for assessing the right of availability of direct sunlight. Classical assessment methods of direct access to sunlight are based on many types of sun-path dia-

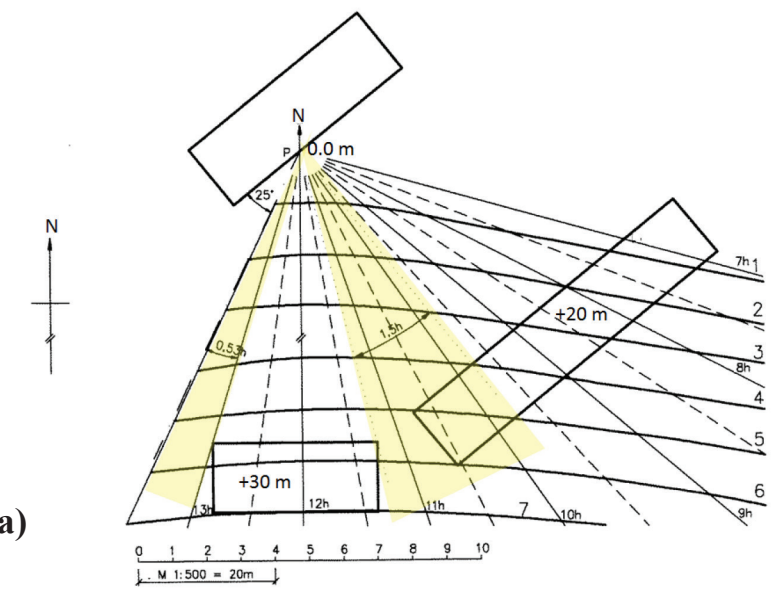

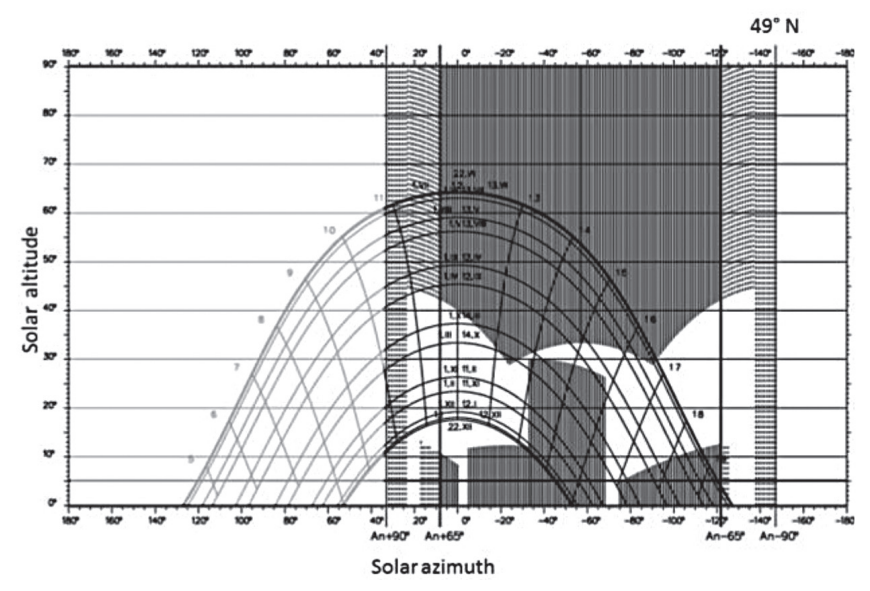

Fig. 4 Cylindrical sun-path diagram generated by the computer program INS (Hraška and Štujber, 2000)

grams or on shadow diagrams. The access to sunlight can be manually calculated using solar charts by applying simple descriptive procedures. Working with solar charts does not require special knowledge, and their advantage is that the results of the assessment have a graphic form that is easily verifiable. The well-known transparent sun-on-reference-point indicator has been used in Slovakia for decades, see Fig. 5a (STN 73 4301:2005). With the help of this indicator, an architect can evaluate the access to sunlight even in complex external shading ratios in several minutes. At present, digitalized versions of the sun-path diagrams are mostly used; these are generally cylindrical and stereographic diagrams. A cylindrical sun-path diagram generated by the INS computer program is on Fig. 4 (Hraška and Stujber, 2000). Methods for assessing shadows cast are usually based on evaluating the length of shadows at a certain time or at the time of shading a particular plot.

The visible sky factor method is also often used to determine the availability of direct sunlight (Johnson and Watson, 1987; Grimmond et al., 2001; Chatzipoulka et al., 2018). On physical models of urban structures, the shadows and the availability of direct sunlight can be clearly monitored using heliodons. Novel computational techniques (Seong et al.,2006; Lobaccaro and Frontini, 2014; Kima and Yin, 2019; Ekici et al., 2019; Ratti and Morello, 2005; Seong et al., 2011; López et al., 2016; De Luca and Dogan, 2019; Lia et al., 2019; Cotton, 1996) and software tools for exploring solar irradiance or the direct access to sunlight on a city scale (for example, HELIOS (Seon et al.,

b)

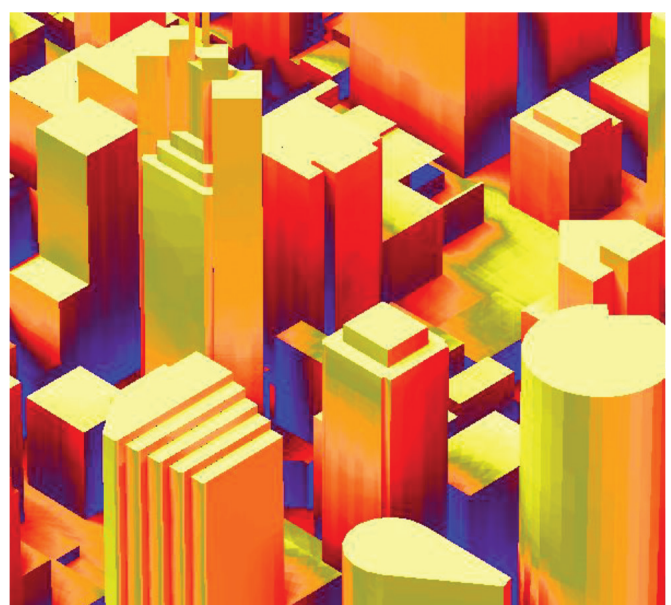

Fig. 5 Simple sun-on-reference-point P indicator (a) (STN 73 4301:2005) and irradiation map of a complex urban environment (b) (Mardaljevic and Rylatt, 2003; Mardaljevic, 2004) 
2006), QuVue (Kima and Yi, 2015) SunScapes (Ratti and Morello)), TOWNSCAPE (Teller and Ayar, 2001), SOLVELOPE (Schiler and Uen-Fang, 1993), and CalcSolar (Noble and Kensek, 1998)) are very sophisticated. However, despite their complexity, not all of them are suitable for evaluating direct access to sunlight rights. The currently published the novel solar envelope method based on solar ordinances for urban planning (De Luca and Dogan, 2019) seems to be very beneficial for the issue analyzed. The evaluation tools based on the total incidence of annual $/$ monthly solar irradiation on building facades in complex urban environments are poorly suited for assessing the rights to direct sunlight. A graphic output of one method of this type is shown in Fig. 5b (Mardaljevic and Rylatt, 2003; Mardaljevic, 2004). The disadvantage of these tools is that they do not provide unambiguous assessment criteria that require direct access to sunlight rights.

They even have a hidden feature to relativize the distribution of solar energy in very dense urban settings, for example, by pointing out that the addition of another very tall building will expand the facade areas capable of the intensive use of solar radiation. Proper use of these tools with actual input data can provide a useful holistic view of the potential solar renewable energy in complex urban environments and more accurate information about solar accessibility, which can be used in many ways in urban planning.

\section{CONCLUSIONS}

Urban design has an extremely broad multidisciplinary nature. The consideration of solar energy in the urban planning process is only one of environmental, social, cultural, economic and other subjects that are associated with dynamic urban creation processes. Environmental issues, "green construction", and social awareness put solar rights at the forefront of urban planning. Direct access to sunlight in dwellings and in some kinds of public spaces should neither be overestimated nor underestimated. Practical use of rights of access to sunlight needs to be balanced with other objectives of integrated planning. Only a few countries in the world have incorporated the right to direct sunlight in their Civil Code. The principle of a "minimum access to direct sunlight for all" should be ensured in a differentiated and sufficiently flexible manner. The solar envelope method alone has no potential for creating a well-functioning city. This method of generating the maximum volumes and shapes of buildings that do not violate the solar/sunlight rights of the surrounding buildings has, in many cases, a distorting effect on both the buildings and urbanism. Solar rights are to be applied differently in different urban zones, consistently in residential areas and, to a reasonably limited extent, in industrial, commercial, or high-rise city areas. The differentiated approach will increase the freedom to create urban developments and help design functional, healthy and comfortable cities for future generations. Such an approach must have a clear legal basis.

\section{Acknowledgement}

This project has been supported by the Ministry of Education, Science, Research and Sport of the Slovak Republic under VEGA contract 1/0050/18 and by the Slovak Research and Development Agency under contracts Nos. APVV-16-0126 and APVV-18-0174.

\section{REFERENCES}

Neeman, E. - Light, W. - Hopkinson, R. G. (1976) Recommendations for the admission and control of sunlight in buildings. Building and Environment, Vol. 11, No. 2, pp. 91-101.

Boubekri, M. (2008) Daylighting, Architecture and Health: Building Design Strategies. 1 ed., Architectural Press, Amsterdam; Boston; London, $160 \mathrm{pp}$.

Holick, M. F (2008) Sunlight, vitamin $D$ and health: A D-lightful story. In: Solar Radiation and Human Health, The Norwegian Academy of Science and Letters, pp. 147-166.

Hobday, R. A. (1997) Sunlight Therapy and Solar Architecture. Medical History, Vol. 42, pp. 455-472.

Littlefair, P. J (2011) Site layout planning for daylight, and sunlight: a guide to good practice. BRE Report, CRC, Garston. Second edition.

Hraška, J. (2004) Solar and daylight rights in Slovakia - their meaning for energy and urban design. In: Proceedings of Contexts of Architecture, 38th International Conference of Architectural Science Association (ANZAScA), Launceston, Australia, 10-12 Nov. 2004, pp. 265-269.

Darula, S. - Christoffersen, J. - Malikova, M. (2015) Sunlight and insolation of building interiors. Energy Procedia, Vol. 78, pp. $1245-1250$.

Hachem, C. - Fazio, F. - Athienitis, A. (2013) Solar optimized residential neighborhoods: Evaluation and design methodology. Solar Energy, Vol. 95, pp. 42-64.
Chynoweth, P. (2009) Progressing the rights to light debate: Part 3: judicial attitudes to current practice. Structural Survey Journal, Vol. 27, No. 1, pp. 7-19.

Hraška, J. (2011) Daylight requirements in sustainable building rating systems. Ingineria Illuminatului (Journal of Lighting Engineering), Vol. 13, No. 2, pp. 5-11.

Cheng, V. - Steemers, K. - Montavon, M. - Compagnon, R. (2006) Urban form, density and solar potential. In: Proceedings of the 23th Conference on PLEA, Geneva, Switzerland, pp. 701-706.

Seong, Y.B. - Lim, J.H - Yeo, M.S - Goh, I.D - Kim, K.W. (2006) HELIOS: Solar rights analysis system for apartment buildings. Solar Energy, Vol. 80, No. 6, pp. 723-741.

Lobaccaro G. - Frontini F. (2014) Solar Energy in urban environment: how urban densification effect existing building. Energy Procedia Journal, Vol. 48; pp.1559-1569.

Lepore, M. (2017) The right to the sun in the urban design. Vitruvio, International Journal of Architecture Technology and Sustainability, Vol. 2, No. 1, pp. 25-43.

Shaviv E., Yezioro, A. (1997) Analyzing Mutual Shading Between Buildings. Solar Energy, Vol. 59, No. 1-3, pp. 83-88.

Capeluto, I.G. - Shaviv, E. (2001) On the use of "Solar Volume" for determining the Urban fabric. Solar Energy, Vol. 70, No. 3, pp. 275-280.

Dogan, T. - Reinhart, C. F. - Michelatos, P. (2012) Urban daylight simulation: Calculating the daylit area of urban designs. Fifth 
National Conference of IBPSA-USA SimBuild, Aug. 1-3, Madison, WI, USA, pp. 613-620.

Kima, H. - Yi, Y.K. (2019) QuVue implementation for decisions related to high-rise residential building layouts. Building and Environment, Vol. 148, pp. 116-127.

Yi, Y. K. - Kim, H. (2015) Agent-based geometry optimization with Genetic Algorithm (GA) for tall apartment's solar right. Solar Energy, Vol. 113, pp. 236-250.

Compagnon, R. (2004) Solar and daylight availability in the urban fabric. Energy and Buildings, Vol. 36, pp. 321-328.

Ekici, B. - Cubukcuoglu, C. - Turrin, M. - Sariyildiz, I. S. (2019) Performative computational architecture using swarm and evolutionary optimisation: A review. Building and Environment, Vol. 147, pp. 356-371.

Ratti, C. - Morello, E. (2005) SunScapes: extending the 'solar envelopes' concept through 'iso-solar surfaces'. In: PLEA2005 - The $22^{\text {nd }}$ Conference on Passive and Low Energy Architecture. Beirut, Lebanon, 6 pp.

Seong, Y. B. - Kim, Y. Y. - Seok, H. T. - Choi, J. M. - Yeo, M. S. - Kim, K. W. (2011) Automatic computation for optimum height planning of apartment buildings to improve solar access. Solar Energy, Vol. 85, pp. 154-173.

López, C. S. P. - Sala, M. - Tagliabue, L. Ch. - Frontini, F. Bouziri, S. (2016) Solar Radiation and Daylighting Assessment Using the Sky-view Factor (SVF) Analysis as Method to Evaluate Urban Planning Densification Policies Impacts. Energy Procedia, Vol. 91, pp. 989-996.

Teller, J. - Azar, S.: TOWNSCOPE II (2001) A computer system to support solar access decision-making. Solar Energy, Vol. 70, No. 3, pp. 187-200.

Mardaljevic, J. - Rylatt, M. (2003) Irradiation mapping of complex urban environments: an image-based approach. Energy and Buildings, Vol. 35, pp. 27- 35 .

De Luca, F. - Dogan, T. (2019) A novel solar envelope method based on solar ordinances for urban planning. Building simulation, Vol. 12, pp. 817-834.

Perez, D. - Kämpf, J. - Wilke, U. - Papadopoulo, M. - Robinson, D. (2011) Citysim Simulation: the Case Study of Alt-Wiedikon, a Neighborhood of Zürich city. CISBAT, Lauzanne, Switzerland, $6 \mathrm{pp}$.

Lia, L. - Leid, Y. - Tanga, L. - Yana, F. - Luoa, F. - Zhua, H. (2019) A 3D spatial data model of the solar rights associated with individual residential properties. Computers, Environment and Urban Systems, Vol. 74, pp. 88-99.

Zhang, J. - Heng, C. K. - Malone-Lee, L. C. - Hii, D. J. C. Janssen, P. - Leung, K. S. - Tan, B. K. (2012) Evaluating environmental implications of density: a comparative case study on the relationship between density, urban block typology and sky exposure. Automation in Construction, Vol. 22, pp. 90-101.

Mohajeria, N. - Gudmundsson, A. - Kunckler, T. - Upadhyay, G. - Assouline, D. - Kämpf, J. H. - Scartezzini, J. L. (2019) A solar-based sustainable urban design: The effects of city-scale streetcanyon geometry on solar access in Geneva, Switzerland. Applied Energy, Vol. 240, pp. 173-190.

Aries, M. B. S. - Aarts, M. P. J. - Van Hoof, J. (2015) Daylight and health: A review of the evidence and consequences for the built environment. Lighting Research and Technology, Vol. 47, pp. 6-27.

Pauley, S. M. (2004) Lighting for the human circadian clock: recent research indicates that lighting has become a public health issue. Medical Hypotheses, Vol. 63, pp. 588-596.

Rea, M. S. - Figueiro, M. G. - Bierman, A. - Hammer, R. (2012) Modeling the spectral sensitivity of the human circadian system. Lighting Research and Technology, Vol. 44, No. 4, pp. 386-396.

Ng, E. (2003) Studies on daylighting design and regulation of high-density residential housing in Hong Kong. Lighting Research and Technology, 2003, Vol. 35, No. 2, pp. 127-139.

Knowles, R. L. (2003) The solar envelope: its meaning for energy and buildings. Energy and Buildings, Vol. 35, pp. 15-25.

Bronin, S. (2009) Solar Rights. Boston University Law Review, Vol. 89, No.1217.

Rosenthal, E. J. (2013) Letting the Sunshine In: Protecting Residential Access to Solar Energy in Common Interest Developments. Florida State University Law Review, Vol. 40, No. 4, Article 6, pp. 995-1025.

Reitze, G. L. (1976) A Solar Rights Zoning Guarantee: Seeking New Law in Old Concepts. Washington University Law Review, 1976, Vol., No. 3, 29 pp.

Morello et al. (2009) Sustainable urban block design through passive architecture, a tool that uses urban geometry optimisation to compute energy savings. In: Proceedings of 26th Conference on Passive and Low Energy Architecture, Quebec City, Canada, 6 pp.

Capeluto, I. G. - Shaviv, E. (2001) On the use of "solar volume" for determining the urban fabric. Solar Energy, Vol. 70, pp. 275-280.

Vartholomaios, A. (2015) The residential solar block envelope: A method for enabling the development of compact urban blocks with high passive solar potential. Energy and Buildings, Vol. 99, pp. 303-312.

Cotton, J. F. (1996) Solid modeling as a tool for constructing solar envelopes. Automation in Construction, Vol. 5, pp. 185-192.

Panão, M. J. N. O. - Gonçalves, H. J. P. - Ferrão, P. M. C. (2008) Optimization of the urban building efficiency potential for mid-latitude climates using a genetic algorithm approach. Renewable Energy, Vol. 33, pp. 887-896.

Stasinopoulos, T. N. (2018) A survey of solar envelope properties using solid modelling. Journal of Green Building, Vol. 13, No. 1, pp. 3-30.

SanPiN 2.2.1/2.1.1.1076-01 "Gigiyenicheskiye trebovaniya k insolyatsii i solntsezashchite pomeshcheniy zhilykh i obshchestvennykh zdaniy i territoriy" (in Russian)

Regulation No. 268/2009 about technical requirements for buildings (Vyhláška č. 268/2009 Sb. o technických požadavcích na stavby. (in Czech)

\section{ČSN 73 4301:2004 Obytné budovy. (Dwellings) (in Czech)}

Regulation No. 532/2002 of the Ministry of Environment of the Slovak Republic. (Vyhláška č. 532/2002 Ministerstva životného prostredia Slovenskej republiky, ktorou sa ustanovujú podrobnosti o všeobecných technických požiadavkách na výstavbu a o všeobecných technických požiadavkách na stavby uživané osobami s obmedzenou schopnost'ou pohybu a orientácie.) (in Slovak) (Decree No. 532/2002 of the Ministry of the Environment 
of the Slovak Republic laying down details on general technical requirements for construction and general technical requirements for buildings used by persons with reduced mobility)

STN 73 4301:2005 Budovy na bývanie. (Dwellings) (in Slovak)

Regulation No. 620/2002 of the Ministry of Infrastructure on the technical requirements to be met by buildings and their placement (Poland)

People's Republic of China, Ministry of Construction (1993) Code of urban residential areas planning \& design. GB 50180-93. Beijing: China Building Industry Press

Urban Land Use Planning System in Japan (2007) 2nd Edition, Japan International Cooperation Agency in Cooperation with Ministry of Land, Infrastructure and Transport, March 2007, 71 pp.

Building Act (2009) Article 61 (Korean Legislation Research Institute, 2009)

DIN 5034-1:2011-07 Daylight in interiors - Part 1: General requirements. (Germany)

BS 8206-2:2008 Lighting for buildings. Code of practice for daylighting. (U.K.)

RT I 2002 - Ehitusseadus (Building act) and standard EVS 894:2008/ A2:2015 Daylight in dwellings and offices. (Estonia)

Technical Guidelines TSG-1-004:2010 "Efficient energy use". (Slovenia)

EN 17037:2018 Daylight in buildings. (European Union)

State Environmental Planning Policy No 65 - Design Quality of Residential Apartment Development (SEPP 65) and the Apartment Design Guide

Auckland design manual (2018) http://www.aucklanddesignmanual.co.nz/sites-and-buildings/apartments
Solar Access Guide (1981) Section 9-9-17, BRC 1981 (City of Boulder, Colorado, USA)

Solar Access (2011) Land Use Ordinance 18.70, City of Ashland, Oregon, USA

Stadt Wien. Info für Nachbarinnen. Juli 2009, Vienna, Austria; www.bauen.wien.at (in German)

Kanton Zürich, Baudirektion, Allgemeine Bauverordnung (ABV), Änderung der Schattenwurfregelung - Erläuterungsbericht Vernehmlassung 30. November 2018 bis 22. März 2019 (in German)

Hraska, J. - Stujber, M. (2000) Manual of program OSV1-UT. 2000, Private publication, Bratislava, Slovakia

Johnson, D. G - Watson, I. D. (1987) Graphical estimation of skyview factors in urban environments. Journal of Climatology, Vol. 7; pp. 193-197.

Grimmond C. S. B. - Potter S. K. - Zutter H. N. - Souch, C. (2001) Rapid methods to estimate sky-view factors applied to urban areas. International Journal of Climatology, Vol. 21, pp. 903-913.

Chatzipoulka, Ch. - Compagnon, R. - Kaempf, J. - Nikolopoulou, M. (2018) Sky view factor as predictor of solar availability on building façades. Solar Energy, Vol. 170, pp. 1026-1038.

Mardaljevic, J. (2004) The quantification of solar access in dense urban environments. Lecture at Hong Kong Polytechnic University, http://www.iesd.dmu.ac.uk/ jm

Schiler, M. - Uen-Fang, P. (1993) Solvelope: an interactive computer program for defining and drawing solar envelopes. In: Proceedings of the 18th National Passive Solar Conference, ASES, Washington, USA, pp. 9-14.

Noble, D. - Kensek K. (1998) Computer generated solar envelopes in architecture. The Journal of Architecture, Vol. 3, No. 2, pp. 117-127. 